\title{
Evaluation of fungicides and nutritional amendments against powdery mildew of pumpkin
}

\author{
Maryam Yousaf ${ }^{1}$, Romana Anjum¹, Nadeem Ahmed ${ }^{4}$, Muhammad Ahmad Zeshan²*, Safdar Ali' ${ }^{\text {, Muhammad }}$ \\ Usman Ghani ${ }^{3}$ \\ ${ }^{1}$ Department of Plant Pathology, University of Agriculture, Faisalabad, Pakistan \\ ${ }^{2}$ Department of Plant Pathology, College of Agriculture, University of Sargodha, Pakistan \\ ${ }^{3}$ Institute of Soil and Environmental Sciences, University of Agriculture, Faisalabad, Pakistan \\ ${ }^{4}$ Department of Plant Pathology, Muhammad Nawaz Sharif University of Agriculture, Multan, Pakistan
}

\begin{abstract}
Received:
May 03, 2019

Accepted:

June 22, 2019

Published:

February 17, 2020

\section{Abstract}

Sphaerotheca fuliginea is the most commonly recorded fungus that cause powdery mildew of cucurbits. The outbreak of this disease occurred in Pakistan in Neelam valley. Current study was conducted to minimize significant economic losses by using different combinations of fungicides and nutritional amendments. Fungicides Bravo (Chlorothalonil) and Score (Difenoconazol) and nutrient solutions of Agsil (Potassium silicate) and Peak (mono potassium phosphate) were applied alone and in combination to manage the disease. Bravo and Score were applied @ 1.5m1/L and $2.5 \mathrm{ml} /$, respectively while $0.1 \%$ solutions of both Agsila and Peak was used. Nutritional amendments were used before the onset of disease and fungicides were applied after the appearance of disease. All the treatments were randomized in three replications. The findings described the combination of fungicides was most efficient in decreasing disease incidence as it reduced the powdery mildew incidence upto $60 \%$. In individual fungicidal applications, Bravo treated plants showed less disease incidence $(36 \%)$ than Score $(40 \%)$. However to avoid from the environmental hazards nutritional amendments is the safest option which gave $50 \%$ reduction in disease incidence. Agsil was more effective than Peak in individual applications and it showed $47 \%$ disease incidence that was $49 \%$ in case of Peak.
\end{abstract}

Keywords: Powdery mildew, Pumpkin, Management, Evaluation

\section{How to cite this:}

Yousaf M, Anjum R, Ahmed N, Zeshan MA, Ali S and Ghani MU, 2020. Evaluation of fungicides and nutritional amendments against powdery mildew of pumpkin. Asian J. Agric. Biol. 8(1):69-74. DOI: 10.35495/ajab.2019.01.038 the original work is properly cited.

\section{Introduction}

Pumpkin is a valuable crop of tropical and temperate zones worldwide (Jun et al., 2006). The fruit contains fat, proteins, carbohydrates and vitamin A (Tellez et al., 2002). Production of pumpkin is affected by genotype selection, sowing date, soil type, insect infestation, diseases and disorders (Schaefer and Renner, 2011). Different bacterial, viral and fungal diseases also disrupt the pumpkin physiology and growth (Vucurovic et al., 2012). Among these, Sphaerotheca fuliginea fungus causes the most 
devastating disease powdery mildew (McGrath and Thomas, 1996). It causes significant reduction in pumpkin quality and quantity (Kiss, 2003).

Sphaerotheca fuliginea cannot be cultured on artificial medium (Kristkova et al., 2009). Firstly mature leaves and stem are infected by the fungus resulting in defoliation, reduced photosynthesis and ultimately low yield (Mossler and Nesheim, 2003). Leaves infected with powdery mildew generally died and wilted as a result plants senesce prematurely (Zitter et al., 1996). Pathogen growth reduces the photosynthetic area of the leaves (Cohen et al., 2007) and cause up to $70 \%$ yield losses (EI-Naggar et al., 2012). Plant infection results in reduced sugar contents that decrease quality of fruits and its market value (Dik and Albajes, 2002).

Race-specific genes through genetic resistance can be used to control Powdery mildew (Kuzuya et al., 2006). Due to the fast genetic changes inside the pathogen population, genetic resistance is not longlasting (Hosoya et al., 2000). Resistant cultivars and fungicides provide best control of powdery mildew disease in cucurbits (McGrath and Thomas, 1996). Quinoxyfen, triflumizole, and penthiopyrad are highly efficient in controlling powdery mildew disease in susceptible varieties (Zhang et al., 2011). Experiment carried out in greenhouse and field conditions to evaluate the efficacy of systemic fungicides (Rubigan 12\% Master 10\%, Topas $10 \%$ Vectra $10 \%$ ) in order to control muskmelon powdery mildew disease that reduced disease severity (Ashour et al., 2009). Fungicide Bayleton significantly reduces the powdery mildew disease incidence as compared to other fungicides (Matheron and Porchas, 2000). Mixing of curative and preventive fungicides is the best tactic to get rid of fungicidal resistance (Briggs et al., 2007). Repeated use of chemicals build up resistance in pathogens against fungicides (Gullino et al., 2000). Despite the fungicide usage is an effective strategy to control plant diseases (Matheron and Porchas 2013) but continuous use may deteriorate the environment. Foliar spray of potassium salts decrease powdery mildew incidence (Kettlewell et al., 2000). Nutrient supplements play an important role for controlling the fungal disease in plants (McGrath, 2001). Silicon decreases the various diseases in monocotyledons and dicotyledons incited by the pathogens such as biotrophic, necrotrophic and hemibiotrophic (Datnoff et al., 2007). Nutrient solutions enhance the tolerance of pumpkin against powdery mildew disease (Savvas et al., 2009). Foliar spray of nutrients enhance the growth and development of plants that leads to improved disease resistance and increased yield. Potassium silicate (KSi) impose suppressive effect on fungal growth and increase plant immunity by forming a physical barrier on leaf surface (Liang et al., 2005). KSi enhance the concentration of free amino acids and defense related enzymes in the plants (Souza et al., 2014). Monopotassium phosphate $\left(\mathrm{KH}_{2} \mathrm{PO}_{4}\right)$ cause malformed conidial and mycelia growth of fungus (Arslan, 2015). $\quad \mathrm{KH}_{2} \mathrm{PO}_{4}$ suppresses disease by affecting pathogen multiplication, metabolism of the plant and stomatal functions (Perrenoud, 1990). It induces systemic acquired resistance by disturbing cell membrane of the target pathogen (Gottstein and Kuc, 1989).

Funigicides and nutrients could be helpful in decreasing disease incidence and enhanced yield. Therefore, different nutrients and fungicides were applied to control the powdery mildew of pumpkin.

\section{Material and Methods}

Experiment was carried out in research field, Department of Plant Pathology, University of Agriculture, Faisalabad (Pakistan) N 3126'1.18968 E 73'3'56.01204. Area used for this experiment was $(54 \times 29$ square foot). Genotype (Mahadeev) seeds were collected from AARI (Ayub Agricultural Research Institute, Faisalabad). The study was focused on disease management so that susceptible variety was selected to get the maximum disease pressure. The experiment was conducted by following randomized complete block design (RCBD) with three replications. The seeds were sown on the bed with a distance of 2 feet.

\section{Inoculation of powdery mildew}

Inoculum was taken from Nuclear Institute for Agriculture and Biology (NIAB), Faisalabad. Conidia was slowly added in two drops of distilled water and counted using a haemocytometer to give a conidial suspension of $3 \times 10^{4} \mathrm{ml}^{-1}$ for inoculation, the upper surface of plant was sprayed evenly with a hand sprayer. Leaves of the plant were inoculated with inoculums of Sphaerotheca fuliginea at the 3-4 leaf stage. In evening, water was also sprayed daily to ensure favorable environmental conditions for disease development. 


\section{Disease assessment}

The following formula was used to calculate incidence of powdery mildew infection

No. of infected plants

Disease incidence $(\%)=---------------------\times 100$

Total plants

(Mir, 2011)

Management of powdery mildew of pumpkin through nutritional supplements and chemicals Two chemicals Bravo (chlorothalonil), Score (Difenocnazole), and their combination with a standard dose were evaluated in a field condition. Two nutritional supplements Agsil (potassium silicate), Peak (mono Phosphate - potassium) and their combination were evaluated against powdery mildew disease.

Table-1: Treatments used against powdery mildew disease of pumpkin

\begin{tabular}{|c|c|c|c|}
\hline Sr.No & Fungicide & Active Ingredient & Recommended \\
\hline T1 & Score & Difenconazole & $250 \mathrm{ml} / 100 \mathrm{~L}$ \\
\hline T2 & Bravo & Chlorothalonil & $150 \mathrm{ml} / 100 \mathrm{~L}$ \\
\hline T3 & Bravo +Score & Chlorothalonil+ Difenconazole & $2.5+1.5 \mathrm{~mL} / \mathrm{L}$ \\
\hline T4 & Agsil & Potassium Silicate & $0.1 \%$ \\
\hline T5 & Peak & Monopotasium Phosphate & $0.1 \%$ \\
\hline T6 & Agsil+ Peak & $\begin{array}{c}\text { Potassium Silicate + } \\
\text { Monopotasium Phosphate }\end{array}$ & $0.2 \%$ \\
\hline T7 & Control & Distilled water & \\
\hline
\end{tabular}

\section{Statistical analysis}

Analysis of variance (ANOVA) was carried out to interpret the data of disease incidence. Software like Statistix 8.1 was used to perform statistical tests. Means were compared using (LSD) test (Steel, 1997).

\section{Results}

All the treatments (fungicides, nutrients and their combinations) contributed towards reducing the powdery mildew disease incidence on pumpkin as compared to control (Table.2). The combination of both fungicides gave the most effective control of fungus (58\%) and disease incidence was significantly decreased $(34 \%)$ as compared to untreated plants $(80 \%)$. Efficacy of individual fungicide remained good and Score was better than Bravo which gave $55 \%$ control of the disease.

Proper plant nutrition strengthens its vigor and stimulates the defense mechanisms. The combination of two nutrient solutions Agsil (Potassium silicate) and Peak (monopotassium phosphate) remained significant in controlling the disease after the individual and combined use of fungicides. When mineral nutrients were used separately, Agsil $(41.25 \%)$ proved better than Peak (38.75\%). Combined use of nutrients gave $46 \%$ reduction in disease incidence. Overall evaluation showed that fungicides most significantly reduced disease incidence in comparison to nutrients.

Table-2: Effect of fungicides and nutrients on powdery mildew disease incidence

\begin{tabular}{|c|c|c|c|}
\hline Serial \# & Treatment & $\begin{array}{c}\text { Disease } \\
\text { incidence }(\%)\end{array}$ & $\begin{array}{c}\text { Decrease over } \\
\text { control }(\%)\end{array}$ \\
\hline T1 & Peak & $49 \mathrm{~b}$ & $38.75 \%$ \\
\hline $\mathrm{T} 2$ & Agsil+Peak & $43 \mathrm{~d}$ & $46.25 \%$ \\
\hline T3 & Bravo & $40 \mathrm{e}$ & $50.00 \%$ \\
\hline $\mathrm{T} 4$ & Agsil & $47 \mathrm{c}$ & $41.25 \%$ \\
\hline T5 & Score & $36 \mathrm{f}$ & $55.01 \%$ \\
\hline T6 & Bravo+Score & $34 \mathrm{~g}$ & $57.51 \%$ \\
\hline \multirow[t]{2}{*}{$\mathrm{T} 7$} & Control & $80 \mathrm{a}$ & \\
\hline & LSD & 1.2 & \\
\hline
\end{tabular}

Different letters show significantly different values in coloumn at $(\mathrm{P}=0.05)$.

Powdery mildew disease incidence significantly reduced after every spray (Table.3). The significant difference was observed in disease incidence in all treatments after first and third spray. The results revealed that disease incidence was most significantly reduced in plants treated with Agsil as compared to others.

Table-3: Efficacy of treatments after each spray

\begin{tabular}{|c|c|c|c|}
\hline \multirow{2}{*}{ Treatments } & \multicolumn{3}{|c|}{ Disease Incidence (\%) } \\
\cline { 2 - 4 } & Spray1 & Spray2 & Spray3 \\
\hline Agsil & $57 \mathrm{~d}$ & $43 \mathrm{~g}$ & $28 \mathrm{j}$ \\
\hline Peak & $56 \mathrm{~d}$ & $52 \mathrm{e}$ & $38 \mathrm{~h}$ \\
\hline Agsil + Peak & $57 \mathrm{~d}$ & $48 \mathrm{f}$ & $34 \mathrm{i}$ \\
\hline Score & $47 \mathrm{f}$ & $33 \mathrm{i}$ & $28 \mathrm{j}$ \\
\hline Bravo & $51 \mathrm{e}$ & $43 \mathrm{~g}$ & $34 \mathrm{i}$ \\
\hline Score + Bravo & $43 \mathrm{~g}$ & $38 \mathrm{~h}$ & $23 \mathrm{k}$ \\
\hline Control & $75 \mathrm{c}$ & $80 \mathrm{~b}$ & $85 \mathrm{a}$ \\
\hline & LSD & 2.1556 & \\
\hline
\end{tabular}

\section{Discussion}

Sphaerotheca fuliginea was isolated from powdery mildew affected plants of cucurbitaceae family (McGrath, 2001). In present study, fungicides gave 
best control of the powdery mildew. Chlorothalonil and difenoconazole effectively reduced the powdery mildew disease incidence. Chaudhury et al. (2000) recorded $46 \%$ control of the disease by using score (difenconazole) that halts fungal growth by interfering with sterol biosynthesis. Minimum disease incidence was recorded in plants treated with fungicide (Score). Score is an effective preventive and curative fungicide due to its quick absorption and high translaminar activity (Jacobsen et al., 2004). These results are in line with Kiran and Ahmad (2005) who recorded maximum powdery mildew disease reduction by the use of Score. Sharma (2006) tested 6 fungicides against powdery mildew and found that difenoconazole is the most effective.

The effect of Bravo (chlorothalonil) was also significant in reducing the pumpkin mildew disease. These results are in line with the results of (Matheron and Porchas, 2013) who evaluated fungicides for the management of powdery mildew of pumpkin. Bravo has multisite mode of action against lower fungi causing powdery mildew (Naidu et al., 2012).

Regular use of chemicals is not cost effective and environmental friendly option. In present study, efficacy of mono-potassium phosphate, potassium silicate and their combination against powdery mildew disease was assessed. Combined effect of both nutrients was better than their individual application. Potassium silicate proved more effective than monopotassium phosphate. Dallagnol et al. (2011) findings supported present results on powdery mildew control through potassium silicate. $S$. fuliginea spore germination was minimum after the application of mono-potassium phosphate and potassium silicate (Menzies et al., 1992). Savvas et al. (2009) observed minimum mildew growth in silicon treated plants. Kettlewell et al. (2000) described significant reduction in fungal colonies as a result of silicon spray. Nofal and Haggag (2006) recorded reduced powdery mildew disease severity in pumpkin fields where potassium silicate was applied before the inoculation of pathogen. The impact of biotic stresses could be minimized by using silicon (Epstein, 2009). According to Ma and Yamaji (2008) silicon acts as physical barrier and host defense modulator against pathogens. Silicon reduced the hyphal elongation and inhibited the fungal mycelium growth under in-vitro conditions (Bekker et al., 2006). Potassium silicate solution reduced the germination of powdery mildew conidia by $40-60 \%$ (Kanto et al., 2004).
Local and systemic induced resistance can be activated in plants by using different nutrients containing phosphate (Reuveni et al., 1998). Mosa (2002) determined the efficacy of $\mathrm{KH}_{2} \mathrm{PO}_{4}$ in reducing powdery mildew disease incidence. Reuveni et al. (2006) indicated that foliar application of potassium phosphate inhibits the fungal growth and found it as an eco-friendly management tactic. Weekly spray of $\mathrm{KH}_{2} \mathrm{PO}_{4}$ gave significant reduction in powdery mildew disease in roses (Pasini et al., 1997). Orober et al. (2002) stated that phosphate induced resistance by the mechanism of localized cell death and generating reactive oxygen species.

\section{Conclusion}

Spray of nutrient solutions before the onset of disease, result in significant reduction of disease incidence. Nutrient application can compensate the deficiencies in plant growth by accelerating the plant physiology. Fungicides alone and in combination were more effective in controlling the powdery mildew disease. Similarly, combined application of nutrients proved better than individual applications in reducing disease incidence.

\section{Disclaimer: None. \\ Conflict of Interest: None. Source of Funding: None.}

\section{References}

Arslan U, 2015. Evaluation of antifungal activity of mono and dipotassium phosphates against phytopathogenic fungi. Fresenius Environ. Bull. 24(3):810-816

Ashour ML, El-Readi M, Youns M, Mulyaningsih S, Sporer F, Efferth T and Wink M, 2009. Chemical composition and biological activity of the essential oil obtained from Bupleurum marginatum (Apiaceae). J. Pharm. Pharmacol. 61(8): 1079-1087.

Bekker T, Kaiser C, Merwe R-vd and Labuschagne $\mathrm{N}, 2006$. In-vitro inhibition of mycelial growth of several phytopathogenic fungi by soluble potassium silicate. South Afr. J. Plant Soil. 23(3): 169-172.

Briggs G, Mansfield D, Moloney B, Gary S and Wegmann T, 2007. The discovery and chemistry of fluopicolide: A new standard for oomycetes 
disease control. Pflanzenschutz nachrichtenBayer-English Edition. 59(2/3): 141.

Chaudhury S, Iqbal J and Mustafa A, 2011. Efficacy of different fungicides for the control of downy mildew of cucumber. J Anim. Plant Sci. 19(4): 202-204.

Cohen R, Leibovich G, Shtienberg D and Paris H, 2007. Variability in the reaction of squash (Cucurbita pepo) to inoculation with Sphaerotheca fuliginea and methodology of breeding for resistance. Plant Pathol. 42(4): 510516.

Dallagnol L, Rodrigues F, Tanaka F, Amorim L and Camargo L, 2011. Effect of potassium silicate on epidemic components of powdery mildew on melon. Plant Pathol. 61(2): 323-330.

Datnoff LE, Elmer WH and Huber DM, 2007. Mineral nutrition and plant disease. Am. Phytopathol. Soc. (APS Press), USA.

Dik AJ and Albajes R, 2002. Principles of epidemiology, population biology, damage relationships and integrated control of diseases and pests, pp. 69-81. In Integrated Pest and Disease Management in Greenhouse Crops. Springer, Germany.

El-Naggar M, El-Deeb H and Ragab S, 2012. Applied approach for controlling powdery mildew disease of cucumber under plastic houses. Pak. J. Agric. Agri. Eng. Vet. Sci. 28: 1-6.

Epstein E, 2009. Silicon: Its manifold roles in plants. Ann. App. Biol. 155(2): 155-160.

Gottstein HD and Kuc JA, 1989. Induction of systemic resistance to anthracnose in cucumber by phosphates. Phytopathol. 79: 176-179.

Gullino ML, Leroux P and Smith CM, 2000. Uses and challenges of novel compounds for plant disease control. Crop Prot. 19(1): 1-11.

Hosoya K, Kuzuya M, Murakami T, Kato K, Narisawa $K$ and Ezura $H$, 2000. Impact of resistant melon cultivars on Sphaerotheca fuliginea. Plant Breed. 119(3): 286-288.

Jacobsen B, Zidack N and Larson B, 2004. The role of Bacillus-based biological control agents in integrated pest management systems: plant diseases. Phytopathol. 94(11): 1272-1275.

Jun HI, Lee CH, Song GS and Kim YS, 2006. Characterization of the pectic polysaccharides from pumpkin peel. Food Sci. Technol. 39(5): 554-561.

Kanto T, Miyoshi A, Ogawa T, Maekawa K and Aino M, 2004. Suppressive effect of potassium silicate on powdery mildew of strawberry in hydroponics. J. Gen. Plant Pathol. 70(4): 207-211.

Kettlewell P, Cook J and Parry D, 2000. Evidence for an osmotic mechanism in the control of powdery mildew disease of wheat by foliar-applied potassium chloride. Eur. J. Plant Pathol. 106(3): 297-300.

Kiran H and Ahmad S, 2005. Relative efficacy of phytobiocides and fungicides in controlling powdery mildew in pea. Sarhad J. Agric. 21: 101102.

Kiss L, 2003. A review of fungal antagonists of powdery mildews and their potential as biocontrol agents. Pest Manage. Sci. 59(4): 475-483.

Kristkova E, Lebeda A and Sedlakova B, 2009. Species spectra, distribution and host range of cucurbit powdery mildews in the Czech Republic, and in some other European and Middle Eastern countries. Phytoparasitol. 37(4): 337-350.

Kuzuya M, Yashiro K, Tomita K and Ezura H, 2006. Powdery mildew (Podosphaera xanthii) resistance in melon is categorized into two types based on inhibition of the infection processes. J. Exp. Bot. 57(9): 2093-2100.

Liang YC, Sun WC and Si J, 2005. Effects of foliarand root-applied silicon on the enhancement of induced resistance to powdery mildew in Cucumis sativus. Plant Pathol. 54: 678-685.

Ma J and Yamaji N, 2008. Functions and transport of silicon in plants. Cell. Mol. Life Sci. 65(19): 3049-3057.

Matheron $M$ and Porchas M, 2000. Impact of azoxystrobin, dimethomorph, fluazinam, fosetyl$\mathrm{Al}$, and metalaxyl on growth, sporulation, and zoospore cyst germination of three Phytophthora spp. Plant Dis. 84(4): 454-458.

Matheron ME and Porchas M, 2013. Efficacy of Fungicides and Rotational Programs for Management of Powdery Mildew on Cantaloupe. Plant Dis. 97(2): 196-200.

McGrath M and Thomas C, 1996. Powdery mildew. pp. 28-30. Academic Press, London, UK.

McGrath MT, 2001. Fungicide resistance in cucurbit powdery mildew: experiences and challenges. Plant Dis. 85(3): 236-245.

Menzies J, Bowen P, Ehret D and Glass AD, 1992. Foliar applications of potassium silicate reduce severity of powdery mildew on cucumber, muskmelon, and zucchini squash. J. Am. Soc. Hort. Sci. 117(6): 902-905.

Mir RA, 2011. Incidence and intensity of powdery 
mildew fungi on the plants of Papilionaceae. New York Sci. J. 25: 23-30.

Mosa AA, 2002. Management of sugar beet powdery mildew by foliar spraying of potassium phosphate salts. Arab Univ. J. Agric. Sci. 10: 1043-1057.

Mossler M and Nesheim O, 2003. Florida crop/pest management profile: Squash. Florida cooperative extension service, Institute of Food and Agricultural Sciences, University of Florida, USA.

Naidu Y, Meon S and Siddiqui Y, 2012. In vitro and in vivo evaluation of microbial-enriched compost tea on the development of powdery mildew on melon. Biocontrol. 57(6): 827-836.

Nofal M and Haggag WM, 2006. Integrated management of powdery mildew of mango in Egypt. Crop Prot. 25(5):480-486.

Orober M, Siegrist J and Buchenauer H, 2002. Mechanisms of phosphate-induced resistance in cucumber. Eur. J. Plant Pathol. 108: 345-353.

Pasini C, D'Aquila F, Curir P and Gullino ML, 1997. Effectiveness of antifungal compounds against rose powdery mildew (Sphaerotheca pannosa var. rosae) in glasshouses. Crop Prot. 16: 251-256.

Perrenoud S, 1990. Potassium and plant health. IPI Research Topics No. 3, second ed. International Potash Institute, Bern, Switzerland, p. 365.

Reuveni M, Harpaz M and Reuveni R, 1998. Integrated control of powdery mildew on field grown mango trees by foliar sprays of monopotassium phosphate fertilizer, sterol inhibitor fungicides and the strobilurin kresoxim methyl. Eur. J. Plant Pathol. 104: 853-860.

Reuveni M, Cohen M and Itach N, 2006. Occurrence of powdery mildew (Sphaerotheca pannosa) in Japanese plum in Northern Israel and its control. Crop Prot. 25(4): 318-323.

Savvas D, Giotis D, Chatzieustratiou E, Bakea M and Patakioutas G, 2009. Silicon supply in soilless cultivations of zucchini alleviates stress induced by salinity and powdery mildew infections. Environ. Exp. Bot. 65(1): 11-17.

Schaefer H and Renner S, 2011. Cucurbitaceae. pp.
112-174. In "Flowering Plants. Eudicots", Springer, Germany.

Sharma IM, 2006. Chemical control of powdery mildew of mango in Himachal Pardesh. Plant Dis. Res. 7(2): 282-283.

Souza LC, Siquera JAM, Silva JLS, Silva JN, Coelho CCR, Neves MG, Oliveira-Neto CF and Lobato AKS, 2014. Effect of proteins, nitrogen and silicates on plant defense. Revista Braselia. 13(2): 117-128.

Steel RGD, 1997. Principles and Procedure of Statistics. 2 Ed. McGraw Hill Book. Co. Inc. New York, USA.

Tellez R, Ayra-Pardo C, Torres D and Gonzalez R, 2002. Insect-resistant transgenic plants: The CIGB experience. Phytopathol. 92: 132-133.

Vucurovic A, Bulajic A, Stankovic I, Ristic D, Berenji J, Jovic J and Krstic B, 2012. Nonpersistently aphid-borne viruses infecting pumpkin and squash in Serbia and partial characterization of Zucchini yellow mosaic virus isolates. Eur. J. Plant Pathol. 133(4): 935-947.

Zhang S, Vallad GE, White TE and Huang CH, 2011. Evaluation of microbial products for management of powdery mildew on summer squash and cantaloupe in Florida. Plant Dis. 95(4): 461-468.

Zitter TA, Hopkins DL and Thomas CE, 1996. Compendium of cucurbit diseases. APS Press St. Paul, MN, USA.

\section{Contribution of Authors}

Yousaf M: Conducted experiment

Anjum R: Supervised research and approved manuscript

Ahmed N: Statistical analysis and data

interpretation

Zeshan MA: Data collection and manuscript write up

Ali S: Literature review and manuscript write up Ghani MU: Helped in experimental layout and spray formulations 